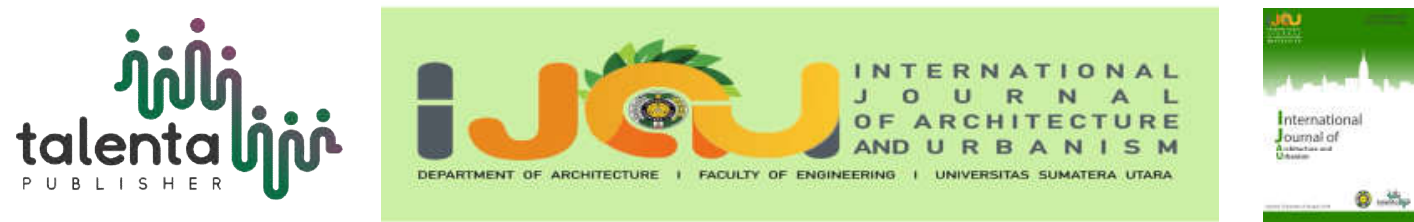

\title{
Reconstruction and Development of Tourism Potentials in the Fishermen's District Village of Medan Belawan
}

\author{
Wahyuni Zahrah $^{1^{*}}$, Ridho Adjie Pangestu ${ }^{1}$ \\ ${ }^{I}$ Department of Architecture, Universitas Sumatera Utara, Medan, Indonesia
}

\begin{abstract}
Belawan Fishermen Village is a Fisherman Village on the edge of Medan City. The fisherman is the biggest livelihood in this village. A Spatial also has a lot of activities / local wisdom as well as traditions such as traditional rowing racing, drying salted fish and catching fish. The problems of the Villages are from poverty, lack of green open space, dirty and smelly environments, waste everywhere, improper laying of buildings, and inadequate water supply. The structures of buildings and building materials in these villages are also included in the inappropriate category. This design aims to make this village as a tourist village, comfortable to live and visited by tourists, and make a friendly village face with the surrounding environment, and can improve the lives of citizens. Also, it can improve the lives of citizens. Realizing the theme of tourism by taking the potential and cultural character and local wisdom which is then implemented in the form of tourism. There are several aspects of design in this design include the following:In the aspect of this village activity, there are 2 activities that are the daily activities of citizens and tourism activities.In the aspect of this village, the site has two accesses, on land in the form of decks that are $2 \mathrm{~m}$ wide as well as ocean circulation that is connected directly to the pier deck of residents' homes.In the aspect of the building, the building in this village uses a structure that is resistant to seawater. In addition to being able to withstand vertical and lateral shocks and buffers that with PVC pipe material filled with cement. Utilities make a biofiltration system that treats waste before entering the sea considering the area of the settlement is a conservation area.
\end{abstract}

Keyword: fisherman, village, tourism

\section{Introduction}

In the era of increasingly advanced globalization and the increasingly high human population, resulting in urban settlements and settlements categorized as slums. Some slum areas are growing at a rate of about $1.37 \%$ annually and have reached 57,800 hectares by 2012 . Medan City has several slums that spread in 7 districts and 18 villages with an area of about 403 hectares. The slum area in Medan reaches 1.5 percent per year from the total area of the area. Medan Belawan subdistrict 61.35 hectares of poor population 17,716 residents, there are slum settlements of 10 ha, one of them in fisherman's village. To overcome the problem of housing and slums in Medan, especially in the Nelayan village, the concept of a good rearrangement is

\footnotetext{
*Corresponding author at: Department of Architecture, Faculty of Engineering, Universitas Sumatera Utara,

Jalan Perpustakaan Gedung J07, Medan 20155, Indonesia

E-mail address: wahyuni.zahrah@gmail.com
} 
the solution. This arrangement is expected to result in improving the quality of the healthy environment and clean layout and offer problem-solving to the narrowness of settlement land in Medan City.

To overcome the problem of poverty in a Fisherman Village should be created a poverty alleviation program that puts the community as subjects in every program so that soon can be realized community welfare [1]. Continuous potential development in a fishing village area becomes an important capital in poverty alleviation through local wisdom-based tourism village. It is expected to be a stimulus for the improvement of economic activities, social, and environmental improvement to realize sustainable societal welfare.Also, it can also make the fishing community into an independent community, productive and make the fishing village into an integrated village.

\section{Literature Review}

The principle of the village is a small community unit equipped with tools to meet their own needs. The village area should be small so that all its parts can be easily reached on foot but large enough to serve its own basic needs, such as open space and markets. The theme of tourism, especially the tourist village is a form of integration between attractions, accommodation and supporting facilities presented in a community life structure that integrates with the ways and traditions that apply [2].There are elements of a tourist village (Figure 1).

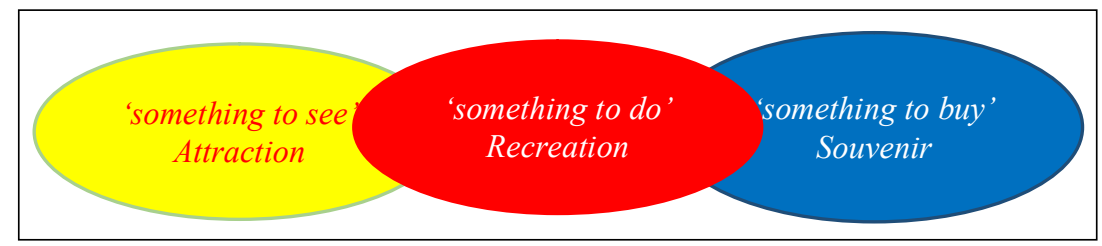

Figure 1. Element of the tourist village

As a cultural product, architecture is essentially influenced by environmental factors, cultural factors, and technology. Environmental factors, including environmental conditions such as geographic, geological, climate, temperature, and so on. Technological factors, including aspects of resource management and technical building skills. Cultural factors, among many definitions of culture, include aspects of philosophy, environmental cognition, perception, norms and religion, social and family structures, economics, and so on [4]. Village tourism, where small groups of tourist stay in or near traditional, often remote villages and learn about village life and the local environment [3]. Belawan Fisherman Village is a village built-in coastal areas, precisely above the swamp of mangrove forest. This village is the majority of the population is Fishermen, also has a lot of traditions / local wisdom.Among the existing traditions is traditional rowing, dried salted fish, caught fish, and so forth.The potential of this tour is expected to improve welfare considering the average population in the fishing village in Belawan is low-income. Also, the arrangement of tourism village development aims to create 
a comfortable settlement to live and visited by tourists, and make the village face is more friendly with the surrounding environment.

\section{Methodology}

In this project, there are several stages of method/approach to problem-solving design/design stages. One of them is Field Survey. In this method there are some aspects of them is the aspect of the activities conducted by interviewing the citizen's activities directly, this site aspect is carried out by examining what structural technology is widely used in the village, the building aspect is done by looking at the form of buildings and customs of the villagers, as well as utility aspects to see what utilities are being used in the village area. To supplement the necessary data in the planning process, a literature study is conducted to complete all the required things. The study of literature is processed through books, journals, articles, deserts, theses and other scientific works. This study was conducted to elaborate the needs of space and the amount of space through the comparative study process.

At analysis stage there are several aspects that need to be considered one of them is the activity, this analysis will generate space and space requirements. In the aspect of the building, this analysis will result in the formation of physical buildings based on the analysis of space and activity. In the utility, aspect will be generated utility concept by conditions around. For design steps, there are several concepts of design one of them is the concept of tread area on this concept generated the overall concept from the environment, circulation patterns, laying of building mass, and the potential of the site. In the concept of space, the concept of the amount of space and the amount of space required. In the concept of the form of building generated the concept of mass formation, space and building functions based on the analysis of community activities. The concept of structure and utility to produce the concept of structure and utility in by conditions around the existing design.

\section{Result and Discussion}

The site is located in the Belawan area of Medan city (Figure 2). Fisherman's village is divided into three village names called Kampung Banjar, Kampung Tengah and Kampung Kerang. By title: "Reconstruction and Development of Tourism Potentials in the Fisherman's District Village of Medan Belawan”. Belawan Fisherman Village is located in Belawan coastal village which can be accessed by using a local boat with $400 \mathrm{~m}$ distance which can be reached in 5 minutes. This village is on a loose marshy, so they build their houses on stage. This village is one of the poor villages on the outskirts of Medan, where the livelihoods in this village are small Fishermen and the average income of low-income citizens. The northern part of the site is Paluh Kurau Village, the southern part is the sea of Belawan, while the eastern part of Palang Nonang and the west is Lombu. 


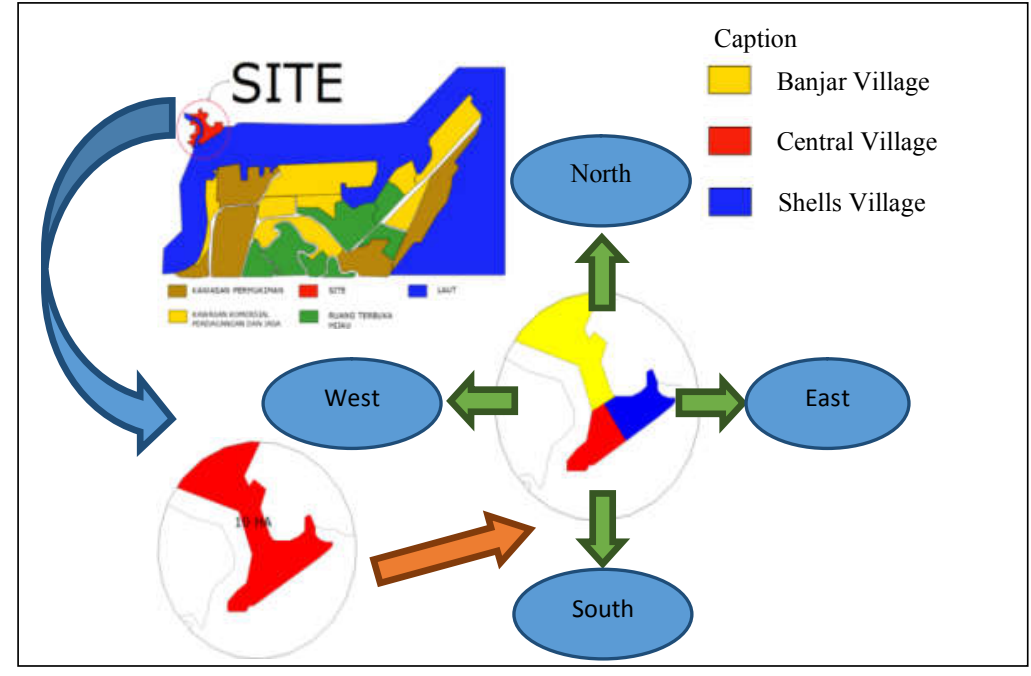

Figure 2. Site location and village distribution

The concept of space and activity programs on this design (Table 1). This village uses a pattern spread that is according to the pattern of the earlier village situation and add some village facilities as a supporter of tourism in the area this village. At the front area, there is a visitor center and a seaside restaurant. And made home-stay mix used residential located spread in settlements and blend with resident's housing (Figures 3 and 4).

Tabel 1. Program space and activity

\begin{tabular}{|c|c|c|c|}
\hline No & Needs & Type Function & Activity \\
\hline \multirow[t]{4}{*}{1.} & \multirow[t]{4}{*}{ Premier } & Shelter + mix used homestay & $\begin{array}{l}\text { Residents residence } \\
\text { Where tourists stay and interact socially } \\
\text { with the surrounding community }\end{array}$ \\
\hline & & Mosque mix pendopo & $\begin{array}{l}\text { Prayer } \\
\text { Place cockroaches meeting and teach ngaji } \\
\text { Sanggar place }\end{array}$ \\
\hline & & Farms & $\begin{array}{l}\text { Place for raising livestock } \\
\text { Workshop for tourist visitors } \\
\text { Guest services }\end{array}$ \\
\hline & & Restaurant & Place tourists to eat \\
\hline \multirow[t]{9}{*}{2.} & \multirow{9}{*}{$\begin{array}{l}\text { Sekunder } \\
\text { Open space }\end{array}$} & Soccer field & $\begin{array}{l}\text { A place for village children and tourists to } \\
\text { play ball }\end{array}$ \\
\hline & & Playground & The place tourists play. \\
\hline & & Retail area & $\begin{array}{l}\text { Where tourists shop for souvenirs made by } \\
\text { residents }\end{array}$ \\
\hline & & Gazebo & A tourist place to relax \\
\hline & & Tribune ball field & Place tourists see the ball game \\
\hline & & Tribune waterfront & $\begin{array}{l}\text { Where tourists see traditional racetrack } \\
\text { matches }\end{array}$ \\
\hline & & Fishing area & The place of the fishing tourists \\
\hline & & Communal sunning area & $\begin{array}{l}\text { Place residents drying salted fish } \\
\text { As a tourist attraction tourist. }\end{array}$ \\
\hline & & $\begin{array}{l}\text { Spot area } \\
\text { Fish citizens }\end{array}$ & $\begin{array}{l}\text { The fish collecting place belongs to the } \\
\text { residents. } \\
\text { As a tourist attraction }\end{array}$ \\
\hline
\end{tabular}




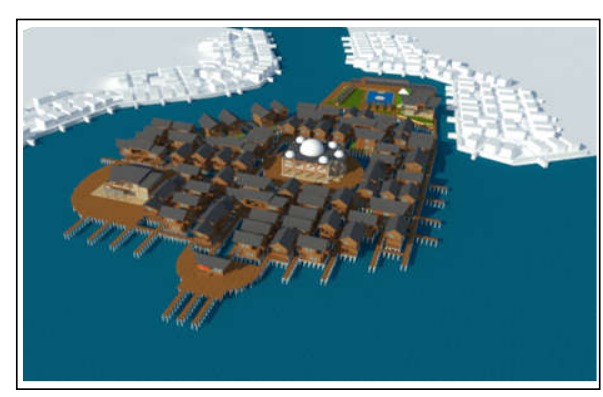

Figure 3. Visible site plan from above

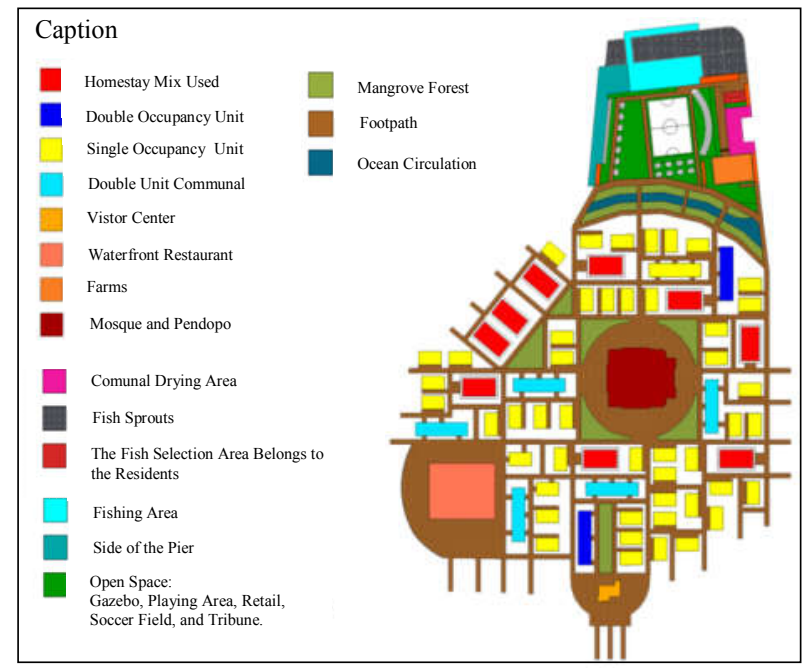

Figure 4. Siteplan

The concept in this area will be made tribune to witness the traditional rowing attractions owned by villagers fishermen as a tourist support facility (Figure 5). So if visitors want to see the rowing attraction can sit in this area and enjoy the show. This tribune is also a place of gathering visitors to each other. The concept of this area will be created for the soccer field, the football field of the retail area, the play area and the gazebos which will all be made to support the tourism and open space of the fishing village (Figure 6). The concept of this cage area also made the fishing area as a tourism support activity (Figure 7).

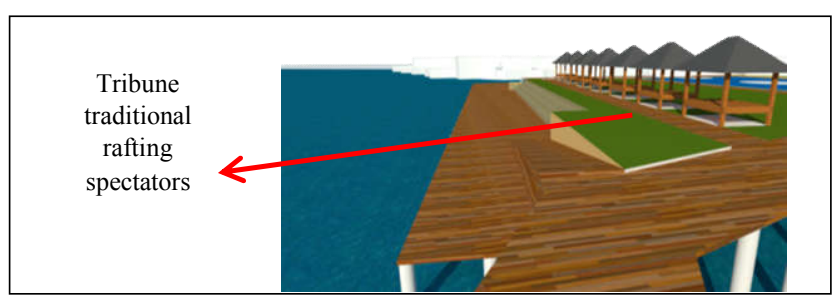

Figure 5. The concept of open space tribunal racing traditional 


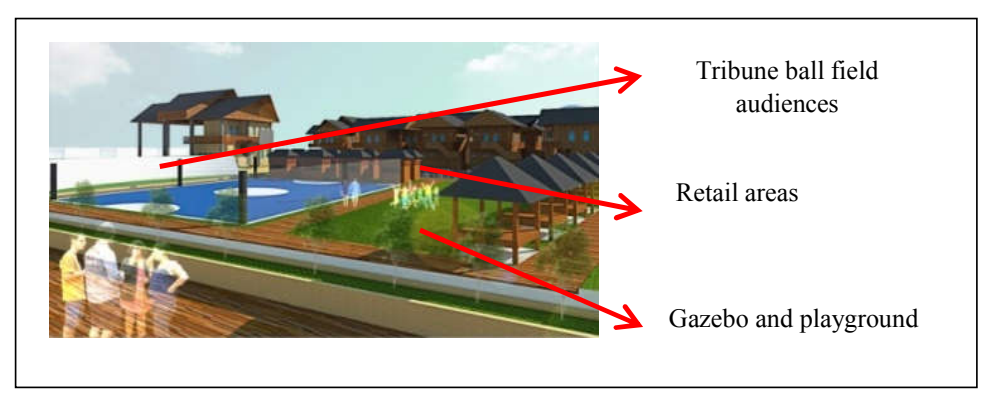

Figure 6. The concept of open space area behind

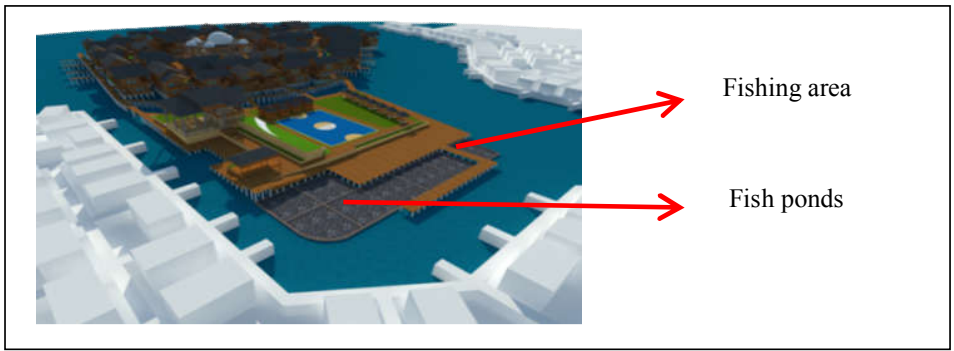

Figure 7. The concept of open space area fishing and fish ponds

The design also includes a special place that accommodates the activities of fish panning residents. Then provided a place for visitors to be able to witness the attraction of buying fish and fisherman villagers and this place is also integrated by farms and fish ponds owned by residents (Figure 8). The concept of circulation in Belawan fishing village area is flexible, circulation placed around the site to make it easier for residents to move. The formation of this circulation is adapted from the habit of people who like to pull over along the edge of the village (Figure 9).

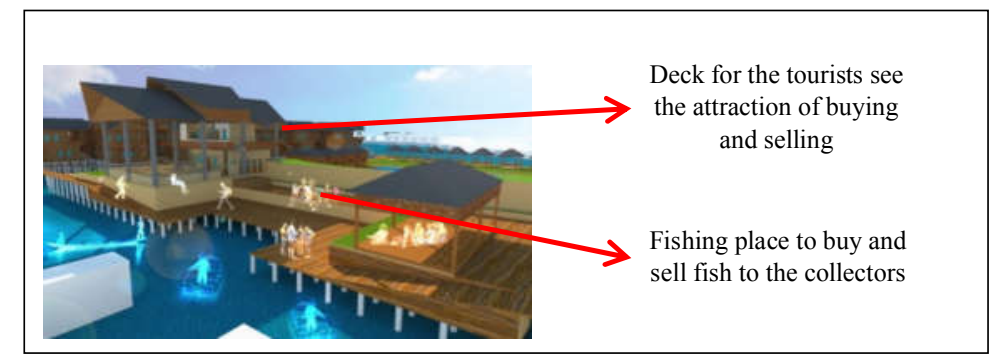

Figure 8. The concept of a place to collect and buy and sell fish

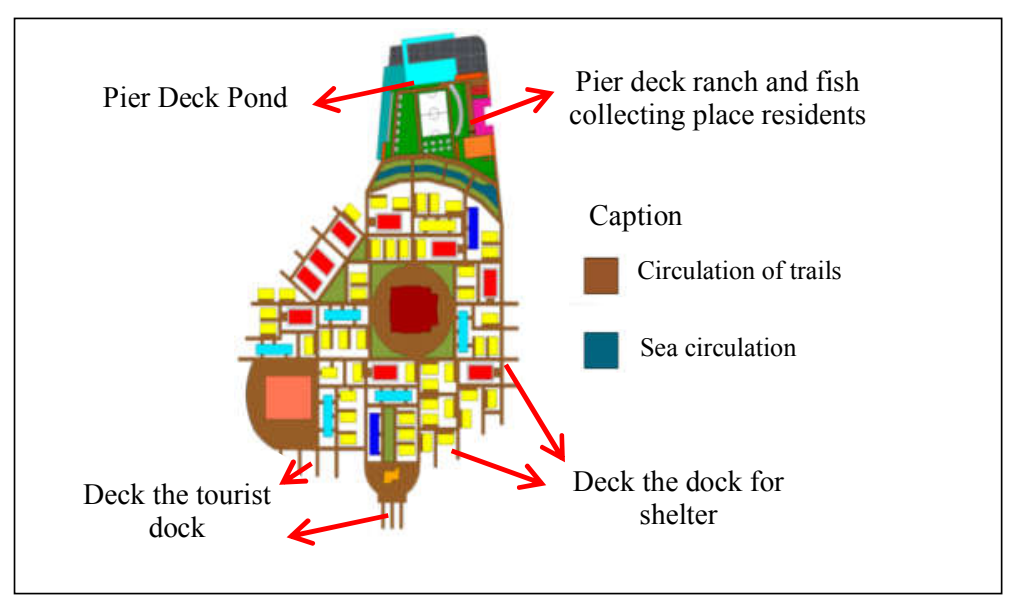

Figure 9. Site Circulation 
Two types of circulation on the site of the ocean circulation and circulation path (Figure 10). Many dock decks around the area of the tread that will ease the activities of citizens and tourists who come, as well as a tourist attraction of the sea for tourist visitors.Land circulation implements a path made of $2 \mathrm{~m}$ wide stage decks to ease pedestrians and connect with zoning to zoning. The mass of buildings in this fishing village is square. Roof formation follows the formation of Malay roof house because the majority of the population in Kampung Nelayan is Malay (Figure 11). Triangular engraving ornaments made as second skins on the building.

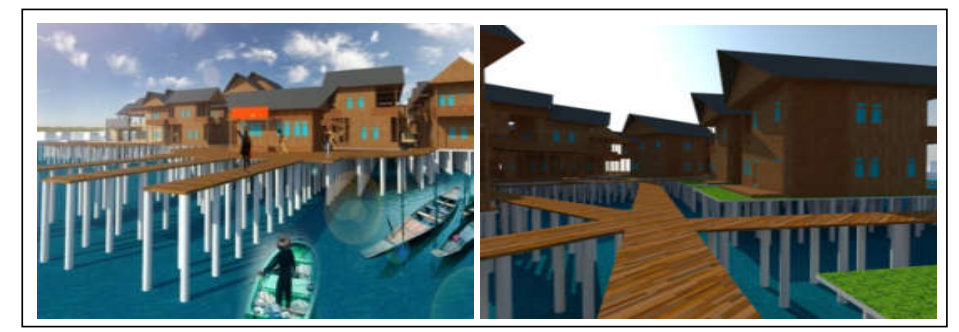

Figure 10. Sea Circulation and Pathways

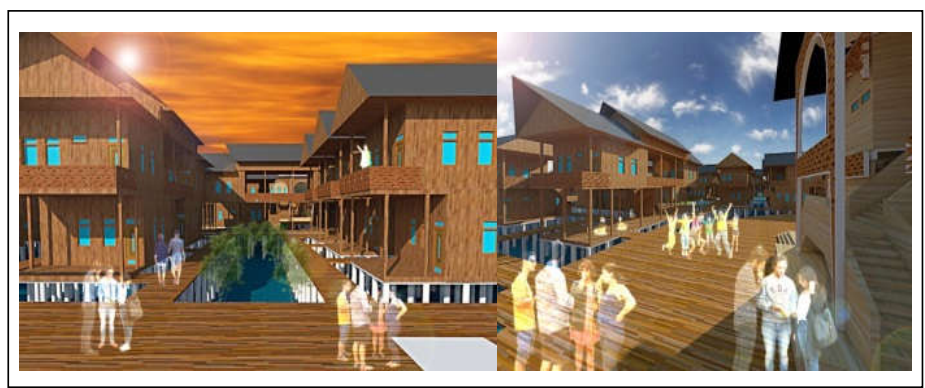

Figure 11. Mass Concept and Residential Architecture

Mass formation of Restaurant and mosque building is no massive wall in the dining room area, all open and facing the sea view and use the second skin ornament after the facade of the dwelling (Figure 12).For a concept of spatial in the shelter, see the base of the building made a communal space for local people to interact with fellow communities, as well as tourist attractions for tourists (Figure 13).

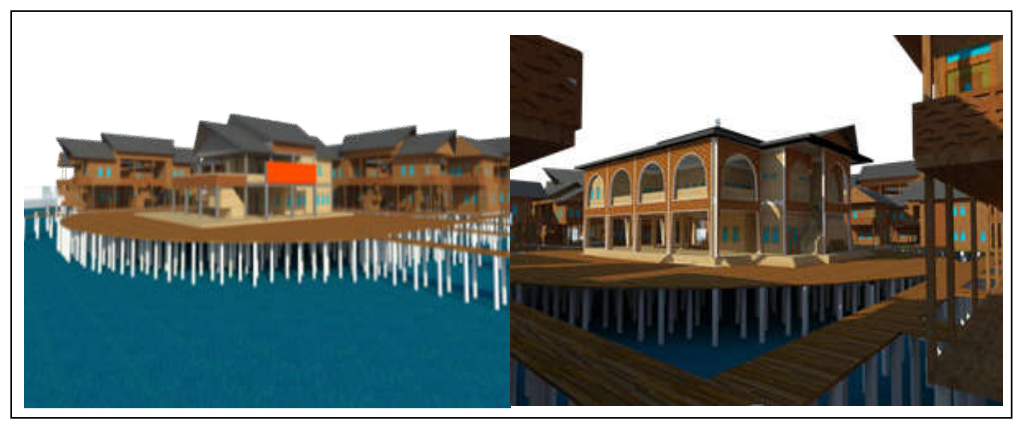

Figure 12. The Concept of Mass Restaurants and Mosque 


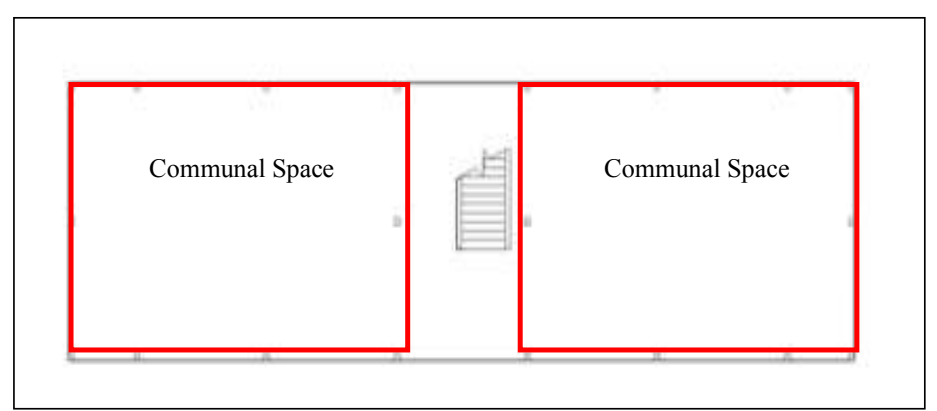

Figure 13. The concept of layout in the occupancy of 1 st floor

In the double unit building occupancy of the front of the terrace is made a bit big for the multipurpose room that later over time, space can be used as a room, warehouse or place of equipment or warehouse for the owner of the house (Figure 14). The 1st floor of the mosque is used as a pavilion area as well as a youth center for cadets gathering and meeting and teaching the children of Belawan village (Figure 15). In this area is also created a stage for the studio attractions or places of worship. The concept of inner space in the function of this farm is mix used with workshop room on the 2nd floor as a tourism support facility that is by learning how to breed goats and cage fish from hatchery process until harvesting (Figure 16).

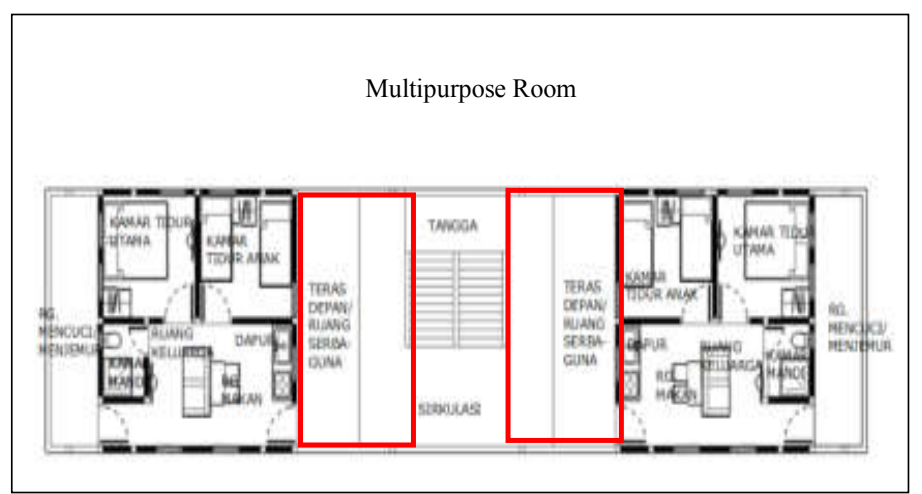

Figure 14. A spatial concept in 2nd-floor occupancy 


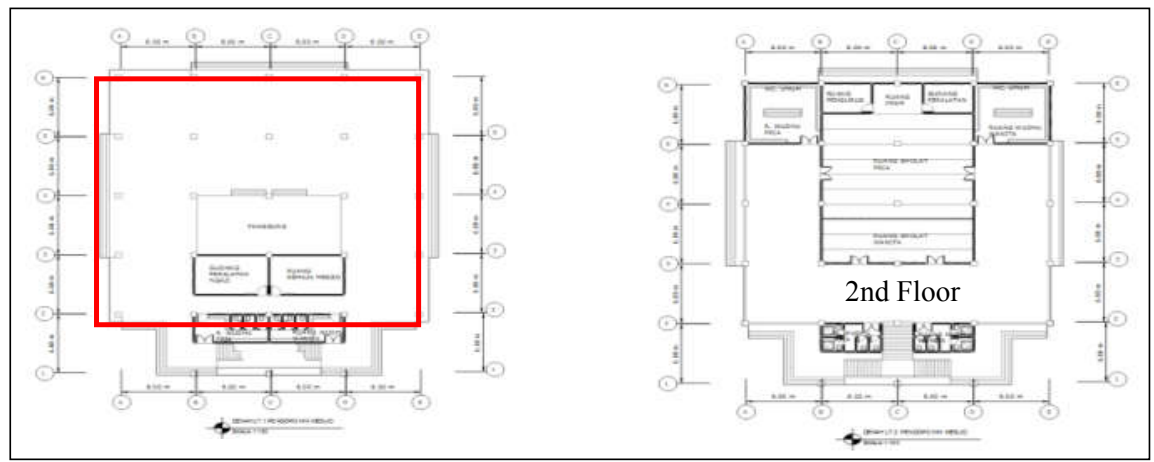

Figure 15. The concept of layout in the mosque mix pendopo

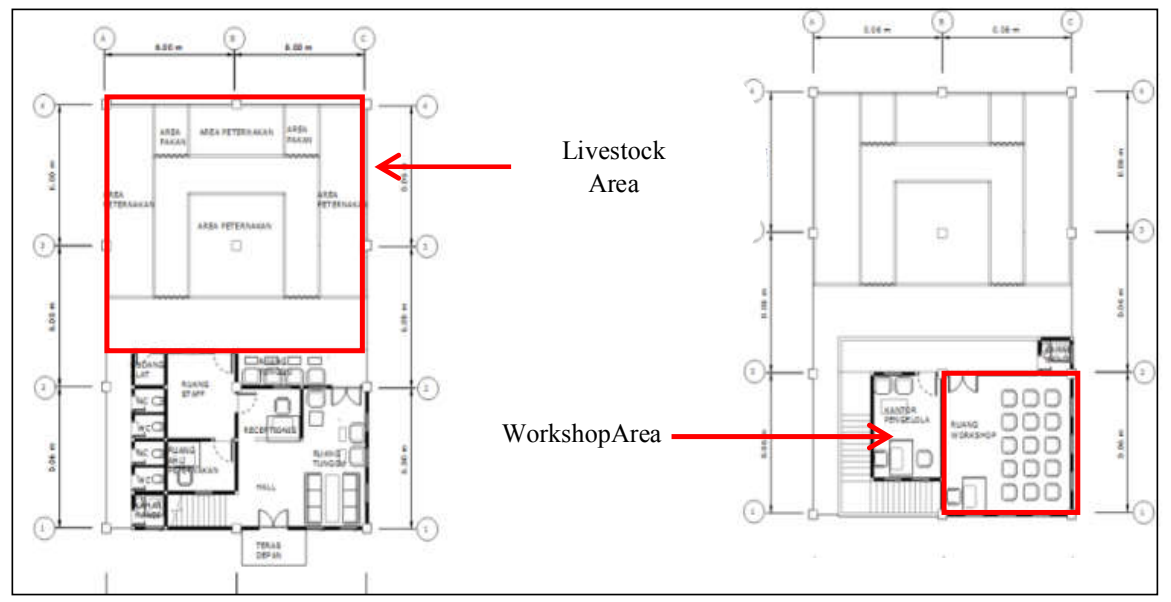

Figure 16. The concept of layout in farms

Building structures built by local communities need a very long process until they find the right structure for them to use as a foundation structure. Initially, they use mangrove wood as its foundation, but after use cannot last long. Then they use the concrete caste structure but the structure is also consumed by tidal sea water, and then they use PVC pipe as a concrete pad for the construction of the foundation, considering that this building is in the swamp area so must use a strong and durable material. And if using this pile construction does not damage the habitats that live in the conservation area of the mangrove forest (Figure 17).

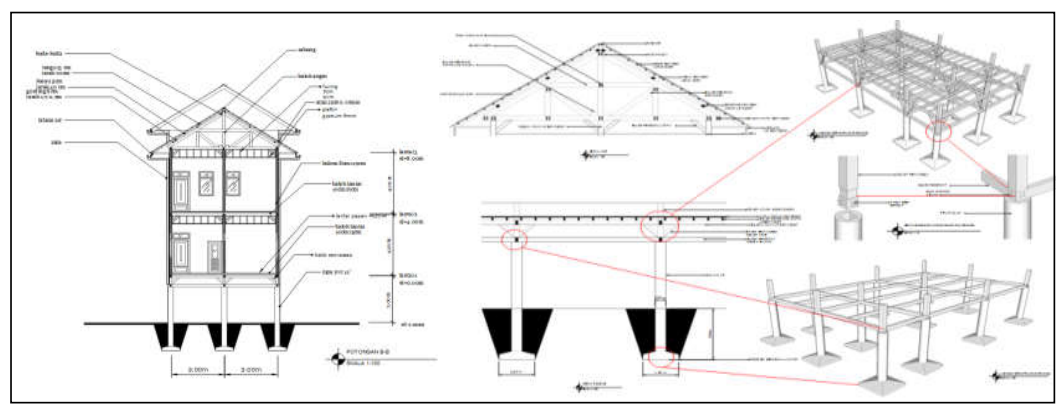

Figure 17. The concept of Structure 
The concept of utility in this design uses a system that does not damage the surrounding environment, considering that the design area is in the conservation area and it is difficult to get clean water supply. For the wastewater disposal from the villagers not to destroy the environment then created a wastewater treatment system in the form of special treatment biofiltration before disposal (Figure 18).

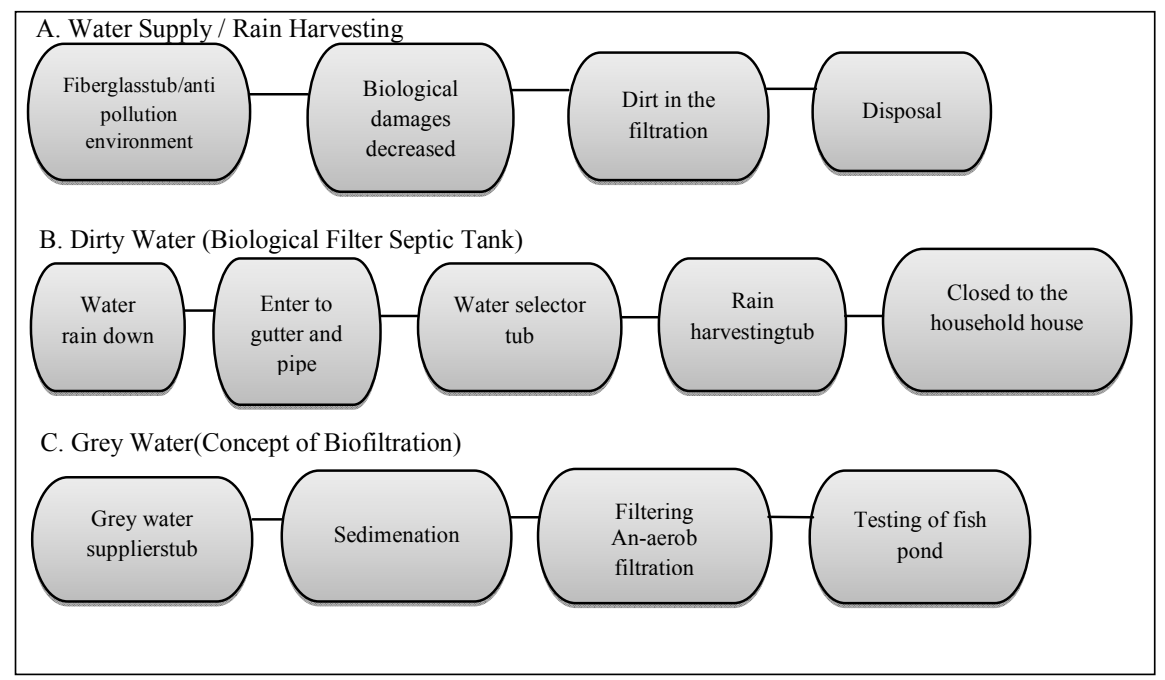

Figure 18. The concept of layout in the occupancy of 1st floor

\section{Conclusion}

The conclusion of this research is to apply the theme of tourism at Belawan Fisherman's village. It is expected that this settlement can overcome housing and settlement problems in a fishermen's village. By re-arrange the fishing village and develop the potential of Fisherman's Village, by raising local culture and traditions (local wisdom). To be a tourist attraction that can increase economic activity, and living standards of residents of the surrounding low-income villages, as well as making the fishing village into an independent village and potential to be made the pilot for other slums as a village that includes elements of the theme tours. Environmentally friendly elements in several aspects of design include; Activities aspect, Site aspect, and Building aspect.

\section{Acknowledgment}

This research is part of the requirement to obtain a bachelor's degree in Architecture Department Universitas Sumatera Utara

\section{REFERENCES}

[1] V. Moeljarto. Pemberdayaan Kelompok Miskin Melalui Program IDT. Jurnal Ilmiah CSIS Edisi, 25. 1996.

[2] W. Nuryanti. Concept, Perspective and Challenges. Makalah bagian dari Laporan Konferensi Internasional mengenai Pariwisata Budaya, 2-3. 1993. 
[3] E. Inskeep. Tourism planning: an integrated and sustainable development approach. Van Nostrand Reinhold. 1991.

[4] I. Altman \& M. M. Chemers. Culture and environment (No. 2). CUP Archive. 1984. 